JOURNAL OF FINANCIAL AND QUANTITATIVE ANALYSIS

December 1978

\title{
ANNOUNCEMENT
}

CALI FOR PAPERS AND PARTICIPANTS

1979 Western Finance Association Annual Meetings

June $21-23,1979$

San Francisco, California

The Annual Meetings of the Western Finance Association will be held June 21-23 at the Ramada Inn at Fisherman's Wharf in San Francisco. Members and friends of the Association are invited to submit papers for presentation at the meetings. Suggested topics include:

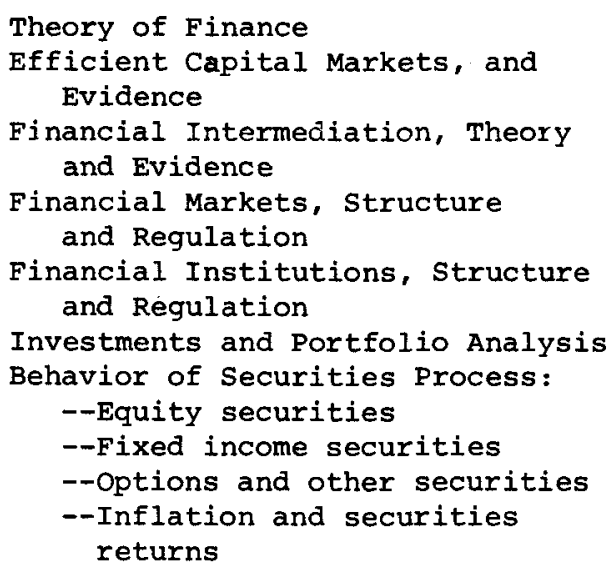

Real Estate Finance

Risk Management and Insurance International Finance

Monetary Policy and Practice

Mergers and Acquisitions

Multinational Finance

Managerial Finance

--Corporate Financial Planning

--Corporate Financial Policies

--In the Not-for-Profit Sector

--In Regulated Environments

- In an Inflationary Environment

Content and Teaching of Finance

Courses

This list should not be considered exhaustive. Papers on other topics of interest to members of the Association are solicited and will be considered.

\section{Submission of Papers}

Four copies of either the completed paper or a five-page abstract, stating the problem, method, data, and implications of findings, should be sent to the Program Chairman no later than November 15, 1978. The papers will be reviewed by the Committee and the authors will be advised of their decision during December 1978.

To maintain objectivity in selection, a separate cover sheet should be included to provide the following information:

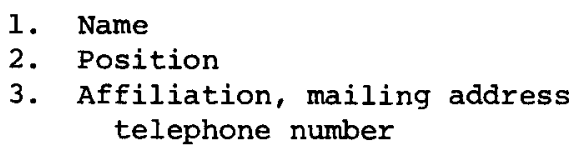

4. Title of Paper

5. Categorization of Paper Topic (as above)

6. Willingness to serve as Discussant or session Chairman 


\section{Other Participants}

Other persons who are willing to serve as Chairpersons or Discussants also are invited to submit the same information. In lieu of items 4 and 5, you should indicate your field(s) of interest in finance.

All papers and communications pertaining to participation on the program should be sent by November 15, 1978 to:

Donald E. Farrar

School of Business

University of Utah

Salt Lake City, Utah 84112 
JOURNAL OF FINANCIAL AND QUANTITATIVE ANALYSIS

December 1978

\author{
ANNOUNCEMENT \\ FINANCIAL MANAGEMENT ASSOCIATION \\ NINTH ANNUAL MEETING \\ CALL FOR 1979 PROGRAM
}

The Financial Management Association brings together practicing financial managers from industry, financial institutions, nonprofit and governmental organizations, and members of the academic community with interests in financial and investment decision making. The ninth annual program, being planned for October 11-13, 1979, at the Sheraton Boston Hotel in Boston, Massachusetts, will stress the interrelationships between theory and practice in financial and investment management. Proposals to participate in the form of completed papers or two-page (maximum) abstracts are solicited for the 1979 meeting. Student contributions are encouraged. All papers and abstracts should be received no later than February 28, 1979. Both members and non-members are invited to respond to the Vice-President-Program, George H. Hempel, Cox School of Business, Southern Methodist University, Dallas, Texas 75275, telephone: (214) 692-2590.

Program Participation:

Meeting Arrangements:

Placement Information:

\section{Annual Meetings}

Dates: October 11-13, 1979

Place: Sheraton Boston Hotel

Boston, Massachusetts

Professor George H. Hempel

Chairman, Finance Subject Area

Edwin I. Cox School of Business

Southern Methodist University

Dallas, Texas 75275

Tel: (214) 692-2590

Professor Frank Campanella

Executive Vice-President

Boston College

Chestnut Hill, Massachusetts 02167

Tel: (617) 969-0100

Professor Donald J. Puglisi

College of Business \& Economics

University of Delaware

Newark, Delaware 19711

Tel: (302) 738-2556 
JOURNAL OF FINANCIAL AND QUANTITATIVE ANALYSIS

December 1978

ANNOUNCEMENT

SOUTHERN FINANCE ASSOCIATION

ANNUAI MEETING

In conjunction with the Southern Economic Association

Dates: $\quad$ November 7-9, 1979

Place: Atlanta Hilton

Atlanta, Georgia

Program: Dr. Richard F. Wacht

President, Southern Finance Association

College of Business Administration

Georgia State University

University Plaza

Atlanta, Georgia 30303

Membership and subscriptions to the JOURNAL OF FINANCIAL RESEARCH

Dr. Bruce D. Fielitz

Secretary-Treasurer, S.F.A.

College of Business Administration

Georgia State University

University Plaza

Atlanta, Georgia 30303

Those interested in participating in the program should mail their completed papers or two-page abstracts to Dr. Wacht no later than April 1, 1979. 